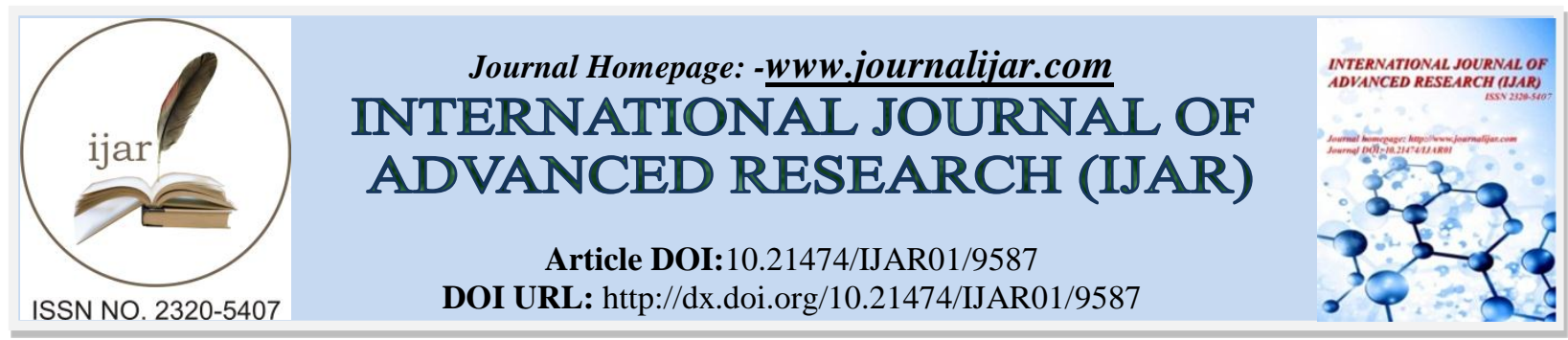

RESEARCH ARTICLE

\title{
EPIDEMIOLOGY OF BURNS AND ITS OUTCOME IN A TEACHING HOSPITAL - A 10 YEARS STUDY.
}

\section{Dr.K.V.N.Prasad ${ }^{1}$ and Dr.P.S.RajaRavi ${ }^{2}$.}

1. MS.MCh(Plastic Surgery),AsstProfessor,Dept of Plastic Surgery, Kurnool MedicalCollege,Kurnool,AP,INDIA.

2. MS.MCh Dept of Plastic Surgery, Kurnool Medical College,Kurnool,AP,INDIA.

\section{Manuscript Info}

Manuscript History

Received: 18 June 2019

Final Accepted: 20 July 2019

Published: August 2019

\section{Abstract}

Copy Right, IJAR, 2019,. All rights reserved.

\section{Introduction:-}

\section{Aim Of The Study}

To analyze the following factors

1. Age

2. Sex

3. Marital status

4. Literacy

5. Employment

6. Cause of burns

7. Total percentage of burns

8. Burn type

9. Burn depth

10. Smoke inhalation

11. First-Aid

12. Flame put-out by

13. Time lag (Delay in approaching Burn unit)

14. Duration of stay (No. of days in the Hospital)

15. Outcome

16. Surgeries (SSG, Flap, Debridement, Amputation)

\section{Materials \& Methods:-}

Place of study:Kurnool Medical College Hospital,Kurnool, Andhra Pradesh, India

Period of study:

Over a period of from January 2009 to December 2018.

Sample size:

11584 Patients

Method of study:

Retrospective study based on Data forms for Burn Injuries .

Corresponding Author:-Dr.K.V.N.Prasad.

Address:-MS.MCh(Plastic Surgery),AsstProfessor,Dept of Plastic Surgery, Kurnool 


\section{Sample selection:}

Inclusion criteria:

1. All In-Patients admitted in Burns Unit of our Hospital from 2009-2018

2. Both sexes

3. All Age groups

\section{Exclusion criteria:}

Patients treated on Out-Patient basis

\section{Results \& Observations:-}

A total number of 11584 patients got admitted from 2009 to 2018, with an average admission rate of 96.5 per month. The parameters as mentioned in Aim of study were studied in detail and are presented below.

\section{Age-Wise Distribution}

Least age found in the data was 3 months and maximum age was 90years. The data was split into four age groups for comparison (Table 1). The number of patients in each group were 2446 (21.1\%), 6338 (54.8\%), 2151 (18.5\%) and $648(5.6 \%)$ respectively.

\section{Sex-Wise Distribution}

In this study $45 \%$ patients were Males and 55\% were Females. The overall Male to Female ratio was 1:1.2 .

\section{Marital Status}

Burn incidence in our study was found to be high in Married persons (66.2\%) followed by Unmarried (15.7\%), Children (18\%) and Divorced persons $(0.1 \%)$.

\section{Literacy}

Burn injuries were more common in illiterates (52.7\%), followed by literates (40.6\%) and children (6.7\%). Literates are further classified into three categories based on their educational qualifications into Low (E.g.: up to $10^{\text {th }}$ class), Medium (E.g.: up to Intermediate) and High (E.g.: up to Graduation)

\section{Employment}

Distribution of Burn injury is high in Unemployed persons (54\%), followed next in order by Employed (19.8\%), Children (12.8\%), Student (12.5\%) and Retired persons (0.9\%)

\section{Etiology (Cause of Burns)}

1. Domestic Burn injuries are significantly high in our series accounting for $94 \%$ of the total burn injuries. Out of them Accidental burns are $57 \%$ followed by Suicidal burns by $42 \%$. Homicidal burns were $0.6 \%$. Mode of injury could not be established in 12 cases .

2. Non-Domestic Burn injuries (burns occuring at the place of work) have accounted for only $6 \%$ of the total burn injuries. Out of them Electrical Burns was $98.5 \%$.

\section{Total Percentage Of Burns}

Distribution of patients according to their Percentage of Burns is shown in the following table. It is evident that a large number of patients (52.6\%) who got admitted in our Burns unit have sustained burns of more than 50\% BSA .

\section{Burn Type}

Flame was the predominant cause of burns $(73.5 \%)$. Electrical burn injury (14\%) was the second most common cause with Domestic Electrical injuries accounting for 892 cases (56.2\%) while Non-Domestic Electrical injuries are 694 cases (43.8\%) of total Electrical Burn injuries. Burns resulting from Scalds, Contact with hot objects and Chemicals are $7.2 \%, 2 \%$ and $0.8 \%$ respectively. Causative agent in 294 cases $(2.5 \%)$ was unknown

\section{Burn Depth}

Majority of the patients sustained Deep burns (68.2\%), followed next in series by All Superficial (17.8\%), Mostly Superficial (11.2\%), and Mixed Burns (2.8\%) . 


\section{Smoke Inhalation}

Out of the total 11584 patients in our series Smoke Inhalation was confirmed clinically in $43.7 \%$ and was suspected in $45 \%$ patients. Mortality was significantly high in Confirmed group (74.7\%) and Suspected group (50.6\%) as compared to patients without inhalation injury and non-flame burns category .

\section{First-Aid}

After sustaining burn injury most of the patients received First-aid in the form of Water (72\%) while others were subjected to Ointment (17.5\%), Ice (3.8\%) or other measures (3\%). No First-aid was given in $3.7 \%$ of patients

\section{Flame Put-Out By}

Following burns the flame was put-out by water in $71.6 \%$ of patients followed by blanket (10.8\%), drop roll technique (1.5\%), hands (1.1\%) and other measures (3.2\%)

\section{Time Lag (Delay In Approaching Burns Unit)}

It is the difference between time of incident and time of starting treatment in burns unit. It was observed in our study that 9223 patients $(84.6 \%$ ) reported to hospital within first 24 hour). Delay of treatment in burns unit and its effect on Outcome, taking into consideration the Percentage of burns .

\section{Duration Of Stay}

Most of the patients who got admitted in our burns unit left the hospital (it includes Discharges, Deaths, and LAMA/Absconding) in the first 10 days (44.6\%) followed next in series by 30 days (41.2\%). Patients got admitted for a minimum period of 1 day to a maximum period of 159 days.

\section{Outcome}

The overall mortality in this period was $56.6 \%$. Year-wise Outcome statistics.

\section{Surgeries}

Total number of Surgeries performed in major O.T under Anesthesia during the period was 2486. Out of them Skin grafting accounted for 57\%, followed next in series by Debridement (16.4\%), Amputation (15.6\%) and Flaps (11\%). - Various flaps which were used in our institute for reconstructing electrical burn injury defects as a primary procedure unemployment (68\% - Table 5), Suicidal (60\%) \& Homicidal (78\%) causes (Table 6.1a).

Total number of Surgeries (Table 16.1) performed in major OT under Anesthesia during the period was 2486. Out of them Skin grafting accounted for 57\%, followed next in series by Debridement (16.4\%), Amputation (15.6\% ) and Flaps (11\%). Minor procedures done under local anesthesia and I.V. sedation like application of Collagen, Fasciotomies, Debridement done at bedside $\&$ in dressing room are excluded from this study.

Type and pattern of Amputations are shown in Table 16.2. Various flaps which were used in our institute for reconstructing electrical burn injury defects as a primary procedure are shown in Table 16.3. Posterior Interosseous Artery flap was the most frequently used flap in reconstruction of electrical burn injury defects of the hand followed next in series by Abdominal Flaps.

\section{Conclusion:-}

Burns represent an extremely stressful experience for the victims, their family in particular and the society at large. The management of burn injury costs very high and drains the economy of both the patient and the treating hospital.

The high mortality in our series could be due to higher Percentage of Burns, Deep burns, Inadequate Staff (shortage of Anaesthesiologist, Nursing staff \& Theatre Assistants), the absence of effective barrier nursing of the patients which is resulting in Cross-Infection and Septicaemia. The other contributing factors for high mortality include inadequate blood availability, Heavy Workload and Lack of Operation Theatre time.

Effective control of infection is not achieved, owing to the lack of isolation of patients, which is due to the deficiency of infrastructure facilities and the cost of expensive antibiotics. 
Economic constraints preclude us from having an infrastructure comparable to the developed world, but somehow comparable survival rates were achieved with conservative line of management despite heavy work load.

A good outcome in a patient is the best motivator for the burn team to continue to strive to improve further.

The problem is very vast but most of them are preventable. We also recommend some measures which could go a long way in minimizing the incidence of this fatal and demanding injury and consequent loss to mankind

1. The kitchen could be safer by cooking on a high platform which is out of reach for kids.

2. Children should be taught the safe use of crackers and electricity.

3. There is a lot of ignorance about the first aid and prevention strategies, leading to higher incidence of major bur ns.

4. The dictum of "pour water on burns victim" should be canvassed into the public through all possible methods.

5. Replacing kerosene lamps with solar lanterns and kerosene stoves either with LPG gas stoves or Solar cookers

6. The high incidence of burns could be reduced by proper education of people about common causes of burns and their prevention.

7. Guidelines for managing minor burns in the rural set-up are formulated and enforced to reduce the existing hea vy workload in the tertiary care hospital like ours.

8. Prevention of Suicidal burns by counseling the patients at different levels viz. Children, Women (especially $\mathrm{p}$ ost-marital), and Anti-stress counseling.

9. Burn prevention programme should be a national programme. This will ensure reduction in the incidence of bur ns.

\section{Bibliography:-}

1. Bhattacharya S. Burn epidemiology - An Indian perspective. Indian J Plast Surg 2009;42:193-4.

2. Forjuoh SN. Burns in low and middle income countries: A review of available literature on descriptive epidemi ology, risk factors, treatment and prevention. Burns 2006;32:529-37.

3. Ahuja RB, Bhattacharya S, Rai A. Changing trends of an endemic trauma. Burns 2009;35:650-6.

4. R.B. Ahuja, S. Bhattacharya. An analysis of 11,196 burn admissions and evaluation of conservative managemen $\mathrm{t}$ techniques. Burns 28 (2002) 555-561.

5. Jayaraman V, Ramakrishnan KM, Devies MR. Burns in Madras: An analysis of 1368 patients in one year. Burn s 1993;19:339-44.

6. Subrahmanyam M. Epidemiology of burns in a district hospital in western India. Burns 1996;22:339-44

7. Subrahmanyam M., Joshi A.V., Analysis Of Burn Injuries Treated During A One-Year Period At A District Ho spital In India, Annals of Burns and Fire Disasters - vol. XVI - n. 2 - June 2003

8. Textbook of Preventive and Social Medicine by K.Park, $19^{\text {th }}$ Edition.

9. Gupta M., Gupta C.K.,Yaduwanshi R.K. et al.: Burn epidemiology: The pink city scene. Burns, 19: 47-51, 1993

10. Sawhney CP, Ahuja RB, Goel A. Burns in India: epidemiology and problems in management. Ind J Burns 1993 ;1:1-4.

11. Davies JWL. The problem of burns in India. Burns 1990;17 (Suppl 1):52-4.

12. Pruitt BA, Mason AD. Epidemiological, demographic and outcome characteristics of burn injury. In: Herndon DN, editor. Total burn care. Philadelphia: W.B. Saunders, 1995. p. 5-15.

13. Sen PK, Kini SV, Lotlikar KD. Analysis of the causes of accidental burns in the city of Bombay during the last $t$ wenty years. J Ind Med Assoc 1963;40:51-6.

14. Sinha JK, Khanna NN, Tripathi K. Etiology and prevention of burns: a review of 170 cases. Ind J Surg 1976;38: $82-6$.

15. Datey S, Murthy NS, Taskar AD. A study of burn injury cases from three hospitals. Ind J Public Health 1981;25 :117-24.

16. Malla CN, Misgar MS, Khan M, Singh S. Analytical study of burns in Kashmir. Burns 1983;9:180-3.

17. Ghuliani KK, Tyagi NK, Narang R, Nayar S. An epidemiological study of burn injury. Ind J Public Health 1988 ;32:24-30.

18. Mc Gill V, Kowal-Vern A, Gamelli RL. Outcome from older burn patients. Arch Surg 2000;135:320-5.

19. MacArthur JD, Moore FD. Epidemiology of burns - the burn prone patient. JAMA 1975;231:259-63.

20. Waller AE, Marshall SW, Langley JD. Adult thermal injuries in New Zealand resulting in death and hospitalisat ion. Burns 1998;24:2251-465.

21. Hytonen M, Honkanen R, Asko-Seljavaara S. Incidence of burns regarding hospitalisation in Finland in 1987. A 
nn Chir Gynaecol 1980;76:218-21

ANNEXURE - I: TABLES \& GRAPHS

Table 1:-Age-wise distribution

\begin{tabular}{|c|c|c|}
\hline & & \\
\hline $\mathbf{0}-\mathbf{1 5}$ & 2446 & $21.1 \%$ \\
\hline $\mathbf{1 6}-\mathbf{3 5}$ & 6338 & $54.8 \%$ \\
\hline $\mathbf{3 6}-\mathbf{5 5}$ & 2151 & $18.5 \%$ \\
\hline$>\mathbf{5 6}$ & 648 & $5.6 \%$ \\
\hline
\end{tabular}

AGE WISE REPORT

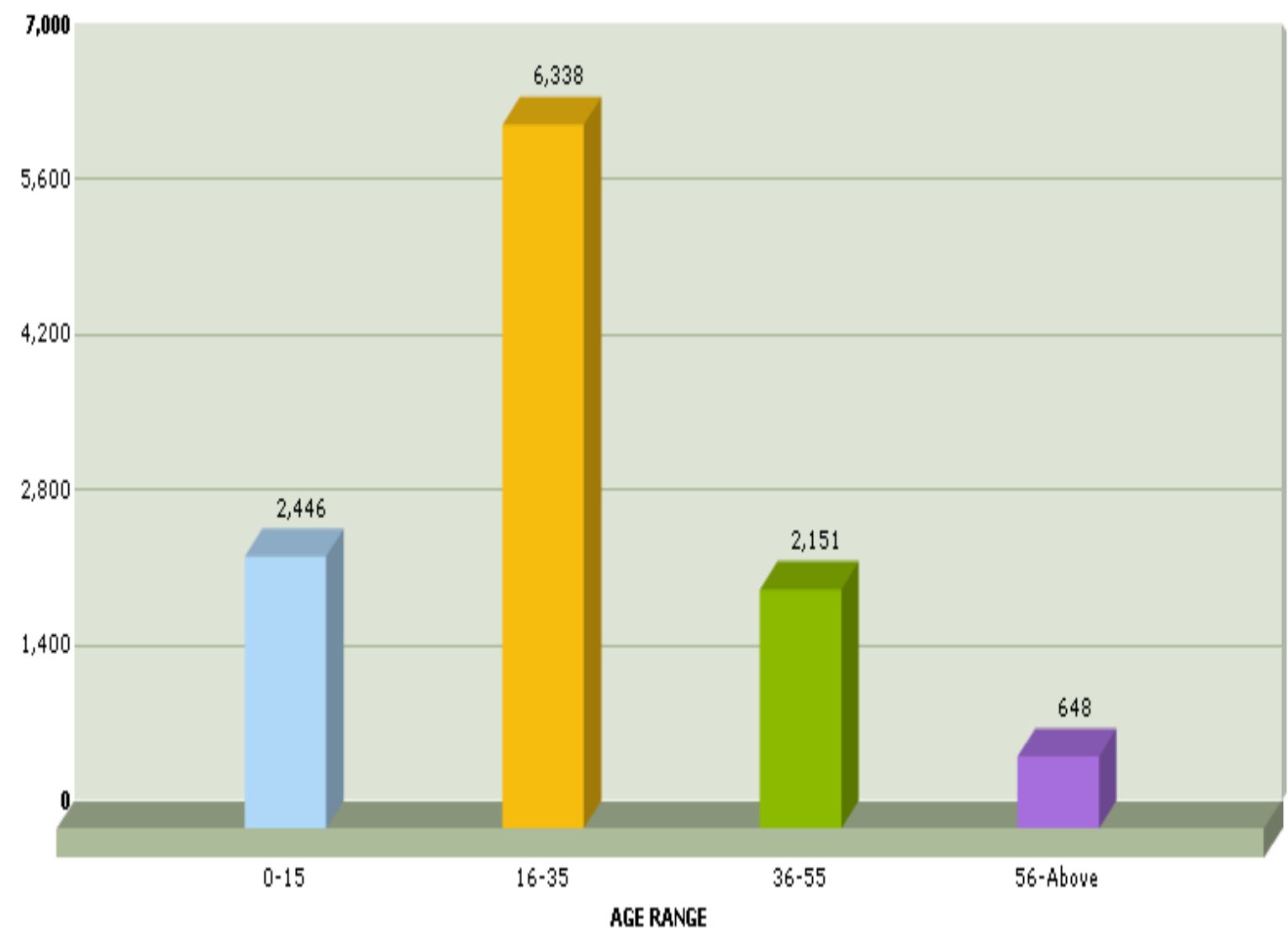

Table 2-Sex-wise distribution

\begin{tabular}{|c|c|c|}
\hline & & \\
\hline Male & 5182 & $45 \%$ \\
\hline Female & 6402 & $55 \%$ \\
\hline
\end{tabular}




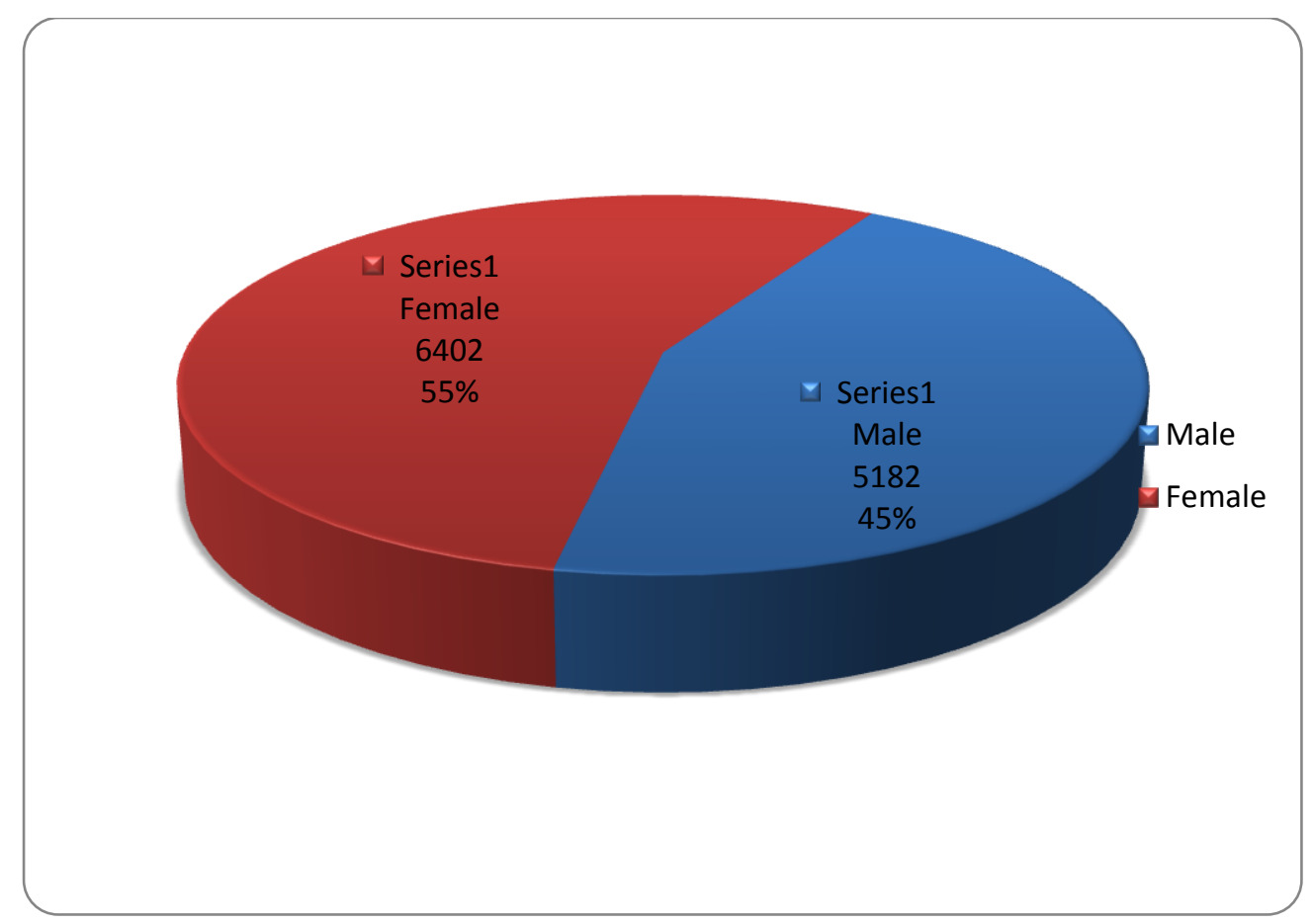

Table 3:-Year-wise Sex distribution

\begin{tabular}{|c|c|c|c|}
\hline & 888 & 400 & 488 \\
\hline & 899 & 338 & 561 \\
\hline & 919 & 348 & 571 \\
\hline & 1030 & 370 & 660 \\
\hline & 1040 & 400 & 640 \\
\hline & 1214 & 521 & 693 \\
\hline & 1342 & 637 & 705 \\
\hline & 1414 & 715 & 699 \\
\hline & 1484 & 772 & 712 \\
\hline
\end{tabular}

\begin{tabular}{|c|c|c|c|c|}
\hline \multirow[b]{2}{*}{ Married } & Male & $2999(39 \%)$ & \multirow[b]{2}{*}{7673} & \multirow[b]{2}{*}{$66.2 \%$} \\
\hline & Female & $4674(61 \%)$ & & \\
\hline \multirow[b]{2}{*}{ Unmarried } & Male & $1014(56 \%)$ & \multirow[b]{2}{*}{1821} & \multirow[b]{2}{*}{$15.7 \%$} \\
\hline & Female & $807(44 \%)$ & & \\
\hline Children & & & 2080 & $18 \%$ \\
\hline Divorced & & & 10 & $0.1 \%$ \\
\hline
\end{tabular}

Table 4:-Literacy status

\begin{tabular}{|c|c|c|c|c|}
\hline \multirow[b]{2}{*}{ Illiterate } & Male & $2145(35 \%)$ & \multirow[b]{2}{*}{6105} & \multirow[b]{2}{*}{$52.7 \%$} \\
\hline & Female & $3960(65 \%)$ & & \\
\hline \multirow{2}{*}{$\begin{array}{c}\text { Low } \\
\left(\mathrm{Eg}: 10^{\text {th }} \text { class }\right)\end{array}$} & Male & $1752(53 \%)$ & \multirow[b]{2}{*}{3296} & \multirow[b]{2}{*}{$28.5 \%$} \\
\hline & Female & $1544(47 \%)$ & & \\
\hline \multirow{2}{*}{$\begin{array}{c}\text { Medium } \\
(\mathrm{Eg}: \text { Intermediate })\end{array}$} & Male & $779(58 \%)$ & \multirow[b]{2}{*}{1354} & \multirow[b]{2}{*}{$11.7 \%$} \\
\hline & Female & $575(42 \%)$ & & \\
\hline \multirow{2}{*}{$\begin{array}{c}\text { High } \\
\text { (Eg:Graduation) }\end{array}$} & Male & $33(59 \%)$ & \multirow[b]{2}{*}{56} & \multirow[b]{2}{*}{$0.4 \%$} \\
\hline & Female & $23(41 \%)$ & & \\
\hline Children & & & 773 & $6.7 \%$ \\
\hline
\end{tabular}


Table 5:-Employment status

\begin{tabular}{|c|c|c|c|c|}
\hline \multirow[b]{2}{*}{ Unemployed } & Male & $1993(32 \%)$ & \multirow[t]{2}{*}{6265} & \multirow[t]{2}{*}{$54 \%$} \\
\hline & Female & $4272(68 \%)$ & & \\
\hline Employed & & & 2283 & $19.8 \%$ \\
\hline Student & & & 1452 & $12.5 \%$ \\
\hline Retired & & & 111 & $0.9 \%$ \\
\hline Children & & & 1473 & $12.8 \%$ \\
\hline & & & & \\
\hline \multirow{3}{*}{ Accident } & Flame & $5227(84 \%)$ & \multirow{3}{*}{6218} & \multirow{3}{*}{$57 \%$} \\
\hline & Electrical & $892(14 \%)$ & & \\
\hline & Chemical & $99(2 \%)$ & & \\
\hline Suicidal & \multicolumn{3}{|r|}{4587} & $42 \%$ \\
\hline Homicidal & \multicolumn{3}{|r|}{63} & $0.6 \%$ \\
\hline
\end{tabular}

Table5-Domestic causes of Burns - Sex wise

\begin{tabular}{|c|c|c|c|c|}
\hline & & No. of Patients & & Percentage \\
\hline \multirow[b]{2}{*}{ Accident } & Male & $3082(49.5 \%)$ & \multirow[t]{2}{*}{6218} & \multirow[t]{2}{*}{$57 \%$} \\
\hline & Female & $3136(50.5 \%)$ & & \\
\hline \multirow[b]{2}{*}{ Suicidal } & Male & $1797(40 \%)$ & \multirow[t]{2}{*}{4587} & \multirow[t]{2}{*}{$42 \%$} \\
\hline & Female & $2790(60 \%)$ & & \\
\hline \multirow[b]{2}{*}{ Homicidal } & Male & $14(22 \%)$ & \multirow[t]{2}{*}{63} & \multirow[t]{2}{*}{$0.6 \%$} \\
\hline & Female & $49(78 \%)$ & & \\
\hline \multirow[b]{2}{*}{ Unknown } & Male & $5(42 \%)$ & \multirow[t]{2}{*}{12} & \multirow[t]{2}{*}{$0.4 \%$} \\
\hline & Female & $7(58 \%)$ & & \\
\hline Total & & & 10880 & $100 \%$ \\
\hline
\end{tabular}

Table 6-Non-Domestic causes of Burns

\begin{tabular}{|c|c|c|}
\hline & & \\
\hline Electrical & 694 & $98.5 \%$ \\
\hline Chemical & 3 & $0.5 \%$ \\
\hline Others & 7 & $1 \%$ \\
\hline Total & $\mathbf{7 0 4}$ & $\mathbf{1 0 0} \%$ \\
\hline
\end{tabular}

Table 7:-Percentage of Burns

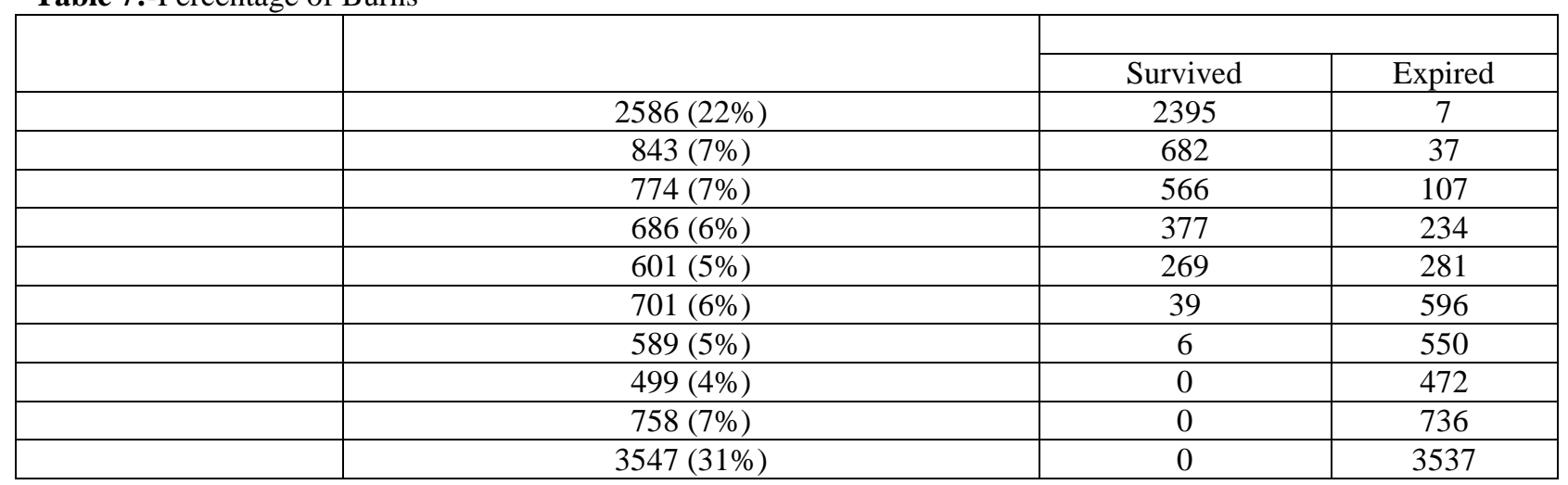

Table 8:-Burn Type

\begin{tabular}{|c|c|c|c|c|}
\hline & \multicolumn{2}{|c|}{} & \\
\hline \multirow{2}{*}{ Flame } & Male & $3454(40 \%)$ & \multirow{2}{*}{8517} & $73.5 \%$ \\
\cline { 2 - 3 } & Female & $5063(60 \%)$ & $14 \%$ \\
\hline Electrical & \multicolumn{3}{|c|}{1586} & \\
\hline
\end{tabular}




\begin{tabular}{|c|c|c|}
\hline Scalds & 844 & $7.2 \%$ \\
\hline Contact & 241 & $2 \%$ \\
\hline Chemical & 102 & $0.8 \%$ \\
\hline Others & 294 & $2.5 \%$ \\
\hline
\end{tabular}

Table 9:-Burn Depth

\begin{tabular}{|c|c|c|}
\hline & & \\
\hline All Superficial & 2058 & $17.8 \%$ \\
\hline Mostly Superficial & 1294 & $11.2 \%$ \\
\hline Mostly Deep & 7899 & $68.2 \%$ \\
\hline Mixed Burns & 333 & $2.8 \%$ \\
\hline
\end{tabular}

Table 10:-Smoke Inhalation

\begin{tabular}{|c|c|c|c|}
\hline & & \multicolumn{2}{|c|}{} \\
\cline { 3 - 4 } & & Survived (\%) & Expired (\%) \\
\hline Confirmed & $5061(43.7 \%)$ & $963(19 \%)$ & $3781(75 \%)$ \\
\hline Suspected & $5226(45 \%)$ & $2441(47 \%)$ & $2648(51 \%)$ \\
\hline No & $956(8.3 \%)$ & $665(70 \%)$ & $101(10 \%)$ \\
\hline Not Flame Burns & $341(3 \%)$ & $265(78 \%)$ & $27(8 \%)$ \\
\hline
\end{tabular}

Table 11:-First-aid measures

\begin{tabular}{|c|c|c|}
\hline Water & 8360 & $72 \%$ \\
\hline Ointment & 2015 & $17.5 \%$ \\
\hline Ice & 430 & $3.8 \%$ \\
\hline None & 423 & $3.7 \%$ \\
\hline Others & 356 & $3 \%$ \\
\hline Water & 8301 & $71.6 \%$ \\
\hline Blanket & 1244 & $10.8 \%$ \\
\hline Drop roll & 175 & $1.5 \%$ \\
\hline Hands & 134 & $1.1 \%$ \\
\hline Not flame burns & 1367 & $11.8 \%$ \\
\hline Others & 363 & $3.2 \%$ \\
\hline
\end{tabular}

Table 12:-Time delay

\begin{tabular}{|c|c|c|c|}
\hline$<\mathbf{2 4}$ hours & 9223 & 5688 & 3535 \\
\hline $\mathbf{2 4} \mathbf{- 4 8}$ hours & 1279 & 733 & 546 \\
\hline$>\mathbf{4 8}$ hours & 389 & 136 & 253 \\
\hline
\end{tabular}

Table 13-Outcome details

\begin{tabular}{|c|c|c|c|c|}
\hline & & \multicolumn{2}{|c|}{} \\
\cline { 3 - 5 } & & Survived & Expired & Absconded/LAMA \\
\hline & 888 & 432 & 417 & 39 \\
\hline & 899 & 285 & 556 & 58 \\
\hline & 919 & 315 & 546 & 58 \\
\hline & 1030 & 420 & 589 & 21 \\
\hline & 1040 & 392 & 629 & 80 \\
\hline & 1214 & 438 & 696 & 104 \\
\hline & 1342 & 461 & 777 & 73 \\
\hline & 1414 & 573 & 768 & 121 \\
\hline & 1484 & 600 & 763 & 120 \\
\hline & 1354 & 418 & 816 & $\mathbf{6 9 3}$ \\
\hline
\end{tabular}




\begin{tabular}{|c|c|c|}
\hline & & $57 \%$ \\
\hline Skin Grafting & 1417 & $15.6 \%$ \\
\hline Amputation & 389 & $16.4 \%$ \\
\hline Debridement & 410 & $11 \%$ \\
\hline Flaps & 270 & $\mathbf{1 0 0} \%$ \\
\hline Total & $\mathbf{2 4 8 6}$ & \multicolumn{1}{c|}{} \\
\hline
\end{tabular}

Table14-

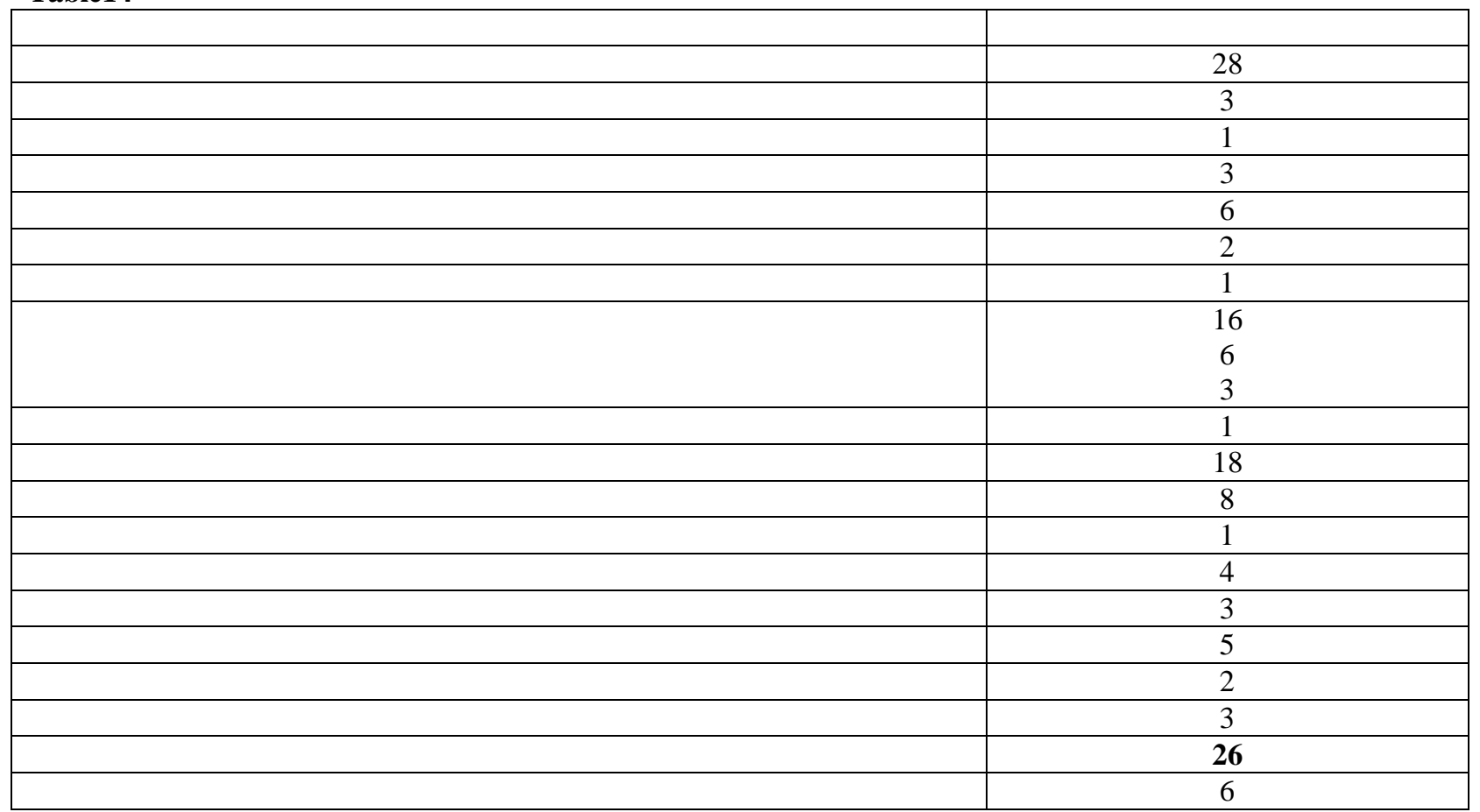

